\title{
Influence of volcanic tephra on photovoltaic (PV)-modules: an experimental study with application to the 2010 Eyjafjallajökull eruption, Iceland
}

\author{
Edgar Zorn ${ }^{1,2^{*}}$ and Thomas R. Walter ${ }^{1}$
}

\begin{abstract}
Large volcanic eruptions may lead to significant tephra dispersion, crossing borders and affecting distant and industrial societies in various ways. While the effects of volcanic ash clouds on the aviation industry have been recognized, damaging effects on the photovoltaic energy sector are poorly investigated. Here we describe the influence of volcanic tephra deposition on photovoltaic (PV) modules that we experimentally analyzed and evaluated. A systematic set of experiments was conducted under controlled conditions using an artificial light source and measuring the electrical power generated from the PV-modules with the aim to determine the dependency of the amount of tephra covering a module and its subsequent loss in power production (measured in voltage and current) as well as the influence of the tephra grain size. We find that a mass of fine tephra has a stronger influence on the PV-modules power generation than the same mass of coarser particles. An application to the fine-grained 2010 Eyjafjallajökull eruption in Iceland and the resulting ash-cloud reveals that the power produced by PV-modules in continental Europe might have been affected significantly. Deposits were thick enough to cause complete failures of PV-modules up to a distance of about $300 \mathrm{~km}$ downwind. Although this distance is largely over the ocean in this particular case, our results imply that similar and larger eruptions of other volcanoes elsewhere might harm commercial or private energy production at distances of hundreds to thousands of kilometers from the volcano. Given that volcanic eruptions are frequent and the fact that the PV-industry is growing rapidly, negative impacts are expected in the future, requiring close tephra dispersion monitoring and PV-maintenance strategies.
\end{abstract}

Keywords: Volcanic tephra, Volcanic ash, Photovoltaic modules, Eyjafjallajökull tephra, Iceland eruption, Volcanic hazard

\section{Background}

Volcanic eruptions produce a number of proximal and distal hazards, acting on various time scales and with different reach. Proximal hazards such as lava-flows, rockfalls, landslides, pyroclastic flows and surges commonly affect the immediate surroundings of a volcano

\footnotetext{
* Correspondence: ezor733@aucklanduni.ac.nz

'Physics of Earthquakes and Volcanoes, GFZ German Research Centre for Geosciences, Telegrafenberg, 14473 Potsdam, Germany

${ }^{2}$ University of Potsdam, Institute of Earth and Environmental Sciences, Karl-Liebknecht-Str. 24-25, 14476 Potsdam, Golm, Germany
}

(few 10s of km). On the other hand, distal hazards can have far more long-range consequences. Specifically gas and tephra may cross oceans and borders to affect regions several hundred to thousand kilometers away (Tilling, 2005, Wilson et al., 2014) as vividly demonstrated by the 2010 Eyjafjallajökull eruption in Iceland (Gudmundsson et al., 2012). In 2010, the dispersion of fine grained tephra led to a number of problems across Europe, including aviation safety and the disruption of an entire industry sector (Gudmundsson et al., 2012). Tephra is known to damage and disrupt critical

\section{定}


infrastructure associated with electricity, water, transportation, wastewater or communication networks and thus may result in significant economic losses (Wilson et al., 2014). General assessments of volcanic tephra fall impacts is a research field that is currently seeing an increase in attention and relevance. Recent studies have primarily focused on infrastructure vulnerability and related parameters (e.g. Jenkins et al., 2014, Oze et al., 2014), but also on more specific impacts of volcanic tephra on important electrical equipment such as high voltage power systems and even laptops exist (Wardman et al., 2012, Wardman et al., 2014, Wilson et al., 2012). However, these previous studies did not consider the photovoltaic sector in detail, despite the high exposure to tephra fall.

Here we study the effects of tephra fall on the power generation of photovoltaic modules. We use laboratory simulations and tephra with different grain sizes to systematically investigate the effects on voltage and current. Furthermore, we discuss the broader implications for PV-modules at scientific monitoring networks surrounding volcanoes as the distant effects and losses at large scale photovoltaic facilities contribute to the renewable energy sector, and related maintenance needs.

We demonstrate in this paper that the vulnerability of the renewable energy sector needs to be considered, especially those markets relying on the rapidly growing solar power industry, which could potentially be affected by tephra dispersion. Because empirical data is limited and is only briefly described for Eyjafjallajökull (Schlosser et al., 2011) and elsewhere (Ota et al., 2012), we evaluate the possible influence of volcanic tephra fall on PV-modules based on systematic laboratory experiments to simulate grain size and concentration-dependent reduction in power generation.

\section{Eyjafjallajökull tephra dispersion over Europe}

The eruption of the Eyjafjallajökull volcano in Iceland lasted from April 14th to May 22nd, 2010 and displayed not only the far-reaching effects of a volcanic eruption, but also the cascading effects on society and industry.

The eruption had a total erupted material of $4.8 \pm 1.2$. $10^{11} \mathrm{~kg}$ with a dense rock equivalent volume of $0.18 \pm$ $0.05 \mathrm{~km}^{3}$ (Gudmundsson et al., 2012). About $80 \%$ of the erupted material was tephra, half of which fell on Iceland and the other half was transported by strong northerly and westerly winds across the ocean towards the UK and continental Europe (Gudmundsson et al, 2012). The directions and isolines of the estimated tephra deposit thickness are illustrated in Fig. 1. Only $0.2 \%$ of the estimated amount of erupted tephra reached Europe (Gudmundsson et al., 2012). For six days (15th to 21st April) civil, industrial and military aviation in Europe was disrupted as a result of the tephra dispersion, with approx. 100,000 canceled flights (O'Regan, 2011). Although difficult to estimate, the economic loss of about 4.7 billion USD in GDP (Oxford Economics, 2010) was unprecedented, even though the ash concentration over Europe was low (32 g/ $/ \mathrm{m}^{2}$ max.) (Devenish et al., 2012). This caused a near complete civil, industrial and military aviation shut down for several days as well as long-lasting political decisions thereafter (O'Regan, 2011). With a VEI (Volcanic Explosivity Index) of 3-4, the eruption was of moderate size (Gudmundsson et al., 2012), but considering that much larger volcano eruptions might occur in Iceland and recurrence intervals of VEI 3-4 eruptions are on the order of less than 5 years (Siebert et al., 2011), it can be inferred that in the future similar or larger volcanic eruptions could produce tephra that will affect Europe.
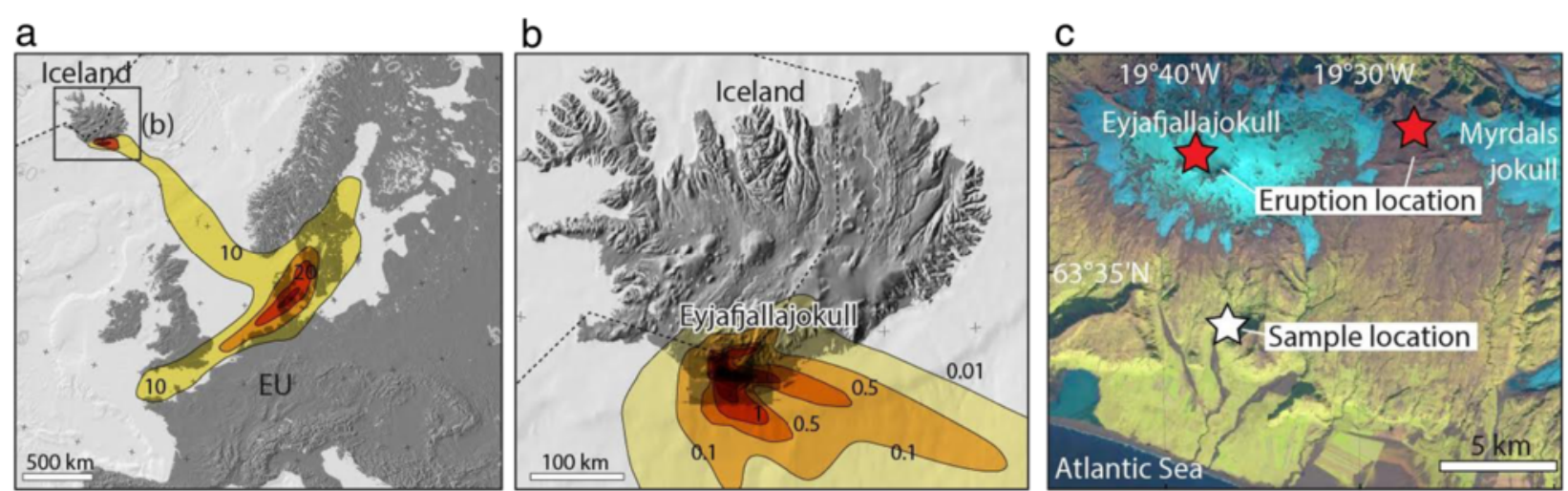

Fig. 1 Shaded relief map of the Eyjafjallajökull eruption tephra in the far field and in the near field. a Tephra distribution in the far field after Devenish et al. (2012) on April 14th 2010, units are in $\mathrm{g} / \mathrm{m}^{2}$. b Tephra deposit thickness in the near field on April 14th to May 22nd after Gudmundsson et al. (2012), units are in cm. c The sampling location for the tephra used in the experimental analysis is shown on a Landsat-8 image and marked with a white star. Red stars indicate the eruption locations. Glaciers (Eyjafjallajökull and Myrdalsjökull) are highlighted in turquoise color 


\section{PV-modules and effects of dust and volcanic tephra}

To convert the solar radiation into electricity, a (PV)module's technology is based on the photoelectric effect (Backus et al., 1990, Saga, 2010): a layer of silicon acts as a semiconductor to collect electrons produced by the impact of a photon, and to gain an electric current. The crystal-structure of the silicon can be monocrystalline, polycrystalline or amorphic, which have different energy conversion efficiencies (Razykov et al., 2011). PVmodules are increasingly used for power generation in remote stations and buildings, water pumping, home systems, global communications, unmanned and remotely operating robotics and space vehicles and for megawatt-scale power plants (Razykov et al., 2011). In 2008 , the total global revenue for the photovoltaic industry was 37 billion USD. The market is rapidly growing at an annual rate of $>40 \%$, globally exceeding $10 \mathrm{GW}$ in 2009 (Razykov et al., 2011).

Most of the PV-energy is produced in Europe, Japan, the United States and especially China. Germany and Spain alone contributed almost $75 \%$ of the gross European production of 2 GW between 2008 and 2009 (Razykov et al., 2011). So far, a decrease in PV-power generation caused by volcanic tephra has not been investigated systematically, although it was shown that tephra coverage could impact this energy sector (Ota et al., 2012).

Previous work (e.g. Sulaiman et al., 2011, Rajput and Sudhakar, 2013) utilized laboratory experiments in order to quantify the drop in power-output of PV-modules as a result of artificial or natural dust contaminants. We use these studies to guide our work, the design of our experimental simulations, the power source, recording units and interpretation. Experimental simulations have been proven to be highly illustrative, where different layers of artificial dust could be investigated under controlled conditions (Beattie et al., 2012, Goossens et al., 1993, Jiang et al., 2011, Kaldellis and Kapsali, 2011).

Dust effectively reduces incoming radiation, and also changes the effects on the radiations angle of incidence (Zorrilla-Casanova et al., 2013). In addition, the operating temperature, rainfall and solar irradiation affect the PV-efficiency, as experimentally and empirically determined (Kumar et al., 2013). Pollution through dust is found to be dependent on rainfall (Zorrilla-Casanova et al., 2013). The initial settling of dust, and possibly also fine ash, promotes the accumulation of more dust, which is why PV-systems in arid climates can experience heavy losses in their power production during dry periods (Kumar et al., 2013). Experimental simulations showed that the reduction of the transmittance of the glass cover decreases, and also depends on orientation and tilt-angle of the PV-module, as well as the dust deposition density and the prevailing wind direction (Elminir et al., 2006). Dust therefore not only reduces the incoming radiation, but also affects the incidence thereof, called soiling (Zorrilla-Casanova et al., 2013). Besides coverage, dust can produce a permanent loss through scratching of the glass surface of the modules (Ju and $\mathrm{Fu}, 2011$ ). This so-called fouling coefficient is used as an evaluation index for assessing the impact of dust on PV-power generators. Naturally, this effect of dust is strongly site dependent. Detailed studies were done for dust accumulation experiments in the Sahara (Mohamed and Hasan, 2012) or in the Sahelian environment (Ndiaye et al., 2013) and elsewhere where aeolian dust is a common problem for PV-modules (Appels et al., 2012, Sorloaica-Hickman et al., 2012). In order to maintain the full performance, regular maintenance and cleaning of the modules is necessary on a daily to weekly basis, dependent on these environmental factors.

Experimental setups commonly used PV-modules with either a natural light or with a constant-power light source (Beattie et al., 2012, Cabanillas and Munguía, 2011, Goossens et al., 1993, Jiang et al., 2011, Kaldellis and Kapsali, 2011). Different conditions of dust accumulation could be simulated, reducing the systems efficiency by $50 \%$ or more. In addition, it was noted that the smaller particle-size of the dust grains might have decreased the power of the modules by a greater amount than larger particles (Sulaiman et al., 2011). Similarly other studies on representative air pollutants (red soil, limestone and carbonaceous fly-ash), and moss (Sulaiman et al., 2014), show that the type and scale of the pollutant specifically affects the energy performance of the PV-modules (Kaldellis and Kapsali, 2011).

These important findings are likely to be just as relevant for volcanic pollutants. The impacts of volcanic tephra on PV-modules have not yet been studied extensively and so far no studies considered the broad range of tephra particle sizes common in volcanic eruptions which ranges from bombs and lapilli to coarse and fine ash, potentially covering PV-modules in dependence to the distance and magnitude of the eruption.

A recent study in Japan showed the significant effect of volcanic products affecting PV-field installations at $\sim 50 \mathrm{~km}$ distance (Ota et al., 2012). In Europe, the effects of the ash plume on the PV-sector were hypothesized to reach as far as Vienna, over $2700 \mathrm{~km}$ away from Eyjafjallajökull (Schlosser et al., 2011). Here we add details on these earlier studies by considering a range of tephra particle sizes and concentrations under laboratory conditions. After detailing the samples used, the following section provides the details on the experimental set up designed to simulate and study the accumulation of volcanic tephra on PV-modules, considering different tephra grain sizes and quantities. We then apply these new findings to the 2010 Eyjafjallajökull tephra dispersion and develop a hypothetical assessment of the PV-module failures that 
can be expected from a similar VEI 3-4 eruption on land. Important implications arise for other and especially larger eruptions (VEI 5 or larger), which are briefly described in the discussion section of this paper.

\section{Methods}

Volcanic eruptions commonly produce tephra with a wide variety of grain sizes. The general classification of volcanic tephra by grain size (Le Bas and Streckeisen, 1991) distinguishes fine ash $(<1 / 16 \mathrm{~mm})$, coarse ash $(1 / 16 \mathrm{~mm}$ to $2 \mathrm{~mm}$ ), lapilli ( $2 \mathrm{~mm}$ to $64 \mathrm{~mm}$ ) and volcanic bombs $(>64 \mathrm{~mm})$. These grain sizes are not found in aeolian and dust effect studies, as they are specific to volcanic tephra fall hazards, however they can impact PV-power generation with eruptions anywhere in the world. To test the effects of these different particle sizes on PV-modules, we collected tephra samples from the 2010 Eyjafjallajökull eruption.

At volcanoes, the sorting gets finer and better the further the tephra is transported from the volcano (Tilling, 2005). However, during the course of an eruption there can be a large variation of the grain sizes with time and distance as the eruption dynamics might change. The following samples and experiments are selected to evaluate and quantify the influence of volcanic tephra on the PV-modules with the example of the Eyjafjallajökull tephra and the main focus on the grain size distribution.

\section{Sampling method and location}

The Eyjafjallajökull volcano is located in the south of Iceland near the coast. It lies beneath a glacier of the same name a few kilometers west of the neighboring Myrdalsjökull. In order to get tephra samples to work with, loose tephra was collected directly after the 2010 eruption and again in 2013 in a valley south of the Eyjafjallajökull, which was approximately seven kilometers from the crater (see Fig. 1c). This location was chosen in consideration of previous studies on the tephra dispersion (Gudmundsson et al., 2012). A map showing the distribution of the tephra is provided in Fig. 1. It shows that the wind conditions at the time of deposition led to a strong southward deposition of the tephra.

The first set of samples used in our experiments were collected shortly after the eruption in 2010 . These tephra samples belong to the eruption period April 18-20, 2010 (M. T. Gudmundsson, pers. commun., 2013) and were investigated in detail before (Gudmundsson et al., 2012). We also collected a second set of samples in 2013. Although the tephra was not fresh, it provides a solid base for analyzing the effect of different grain sizes on PVmodules. Due to remobilization of the 2013 samples, we found a very good sorting in the range of coarse ash. In addition we could use fine ash and lapilli, which were the easiest to sort out of the 2010 samples. As a result, three grain sizes could be used for the experiments: fine ash, coarse ash and lapilli.

\section{Sample description}

Each sample was examined for its appearance and for its physical and chemical properties using scanning electron microscopy (SEM) (Zorn, 2014).

The fine ash has a trachybasaltic composition (Gudmundsson et al., 2012) and dark gray color. It is poorly sorted, angular, and has grain sizes ranging from very fine to fine $(<60 \mu \mathrm{m}$, Fig. $2 \mathrm{a})$. Coarse clasts are rare,

\section{Tephra samples from Eyjafjallajokull}

\section{a}

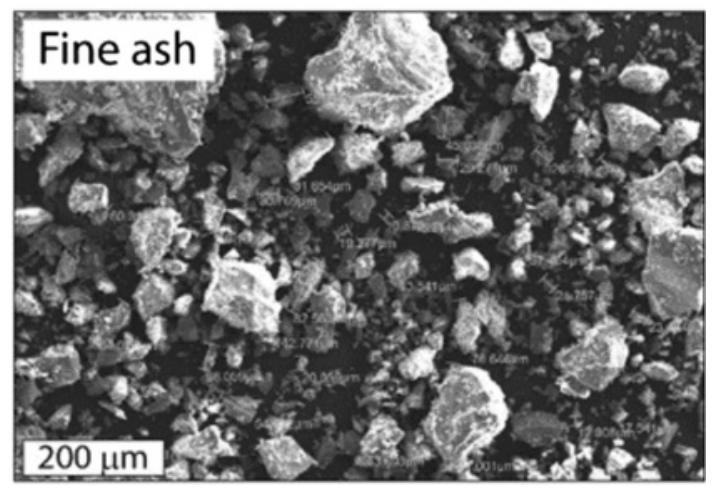

b

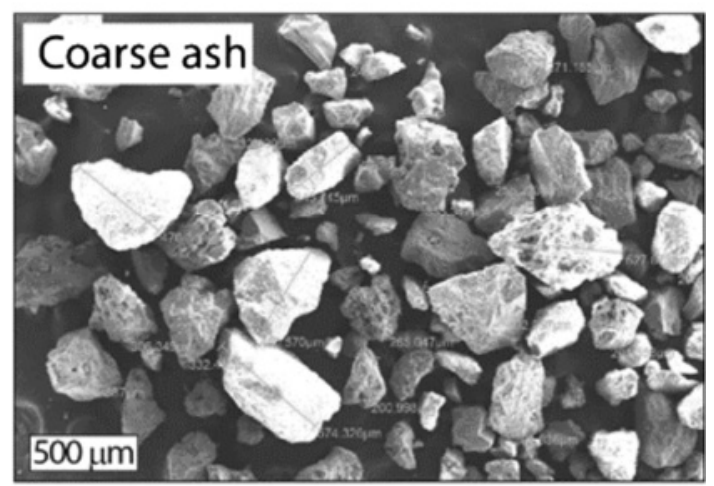

C

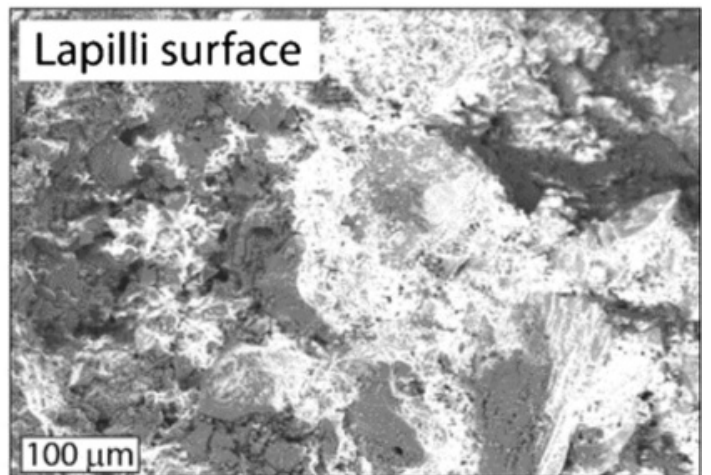

Fig. 2 SEM-images of the fine ash (a), the coarse ash (b) and the lapilli (c) samples from the 2010 Eyjafjallajökull eruption. See text for explanations 
but present. The sample is largely aphyric, no minerals are distinguishable. When thrown into the air, the finest particles can remain suspended in the air for several seconds before settling on the ground.

The coarse ash (Fig. 2b) has a very dark gray to black color and has grain sizes mostly between 200-600 $\mu \mathrm{m}$. As in the previous sample, the clasts are very angular and have a high sphericity. On the surface of many clasts, tiny bubbles can be observed reminiscent of a pumiceous structure. On larger clasts it is also possible to recognize idiomorphic plagioclase-crystals.

The lapilli sample (Fig. 2c), is also trachybasaltic in composition (Gudmundsson et al., 2012) and has a dark gray color. It is very well sorted with an average grain size of $1.48 \mathrm{~cm}$. The clasts are well rounded, brittle and produce fine ash on collision or when falling. As the clasts are very large, the SEM only shows the surface texture. Figure 2c therefore shows a part of a single clast only.

\section{Experimental setup}

The experiments to measure the effect of tephra on PVmodules were set-up according to previous dust-effect studies (Kumar et al., 2013, Sulaiman et al., 2011). We repeated each experiment for two different PV-modules, placed horizontally; in total we ran over 140 simulations. Artificial light was produced by two warm white $400 \mathrm{~W}$ flood lights, providing 8545 lumen each as well as a broad-beamed and high-intensity illumination that was positioned vertically $0.8 \mathrm{~m}$ above the PV-module as illustrated in Fig. 3. We repeated each experiment with different modules, here results for module 1 and module 2 are described. The technical data for the two modules is provided in Table 1.

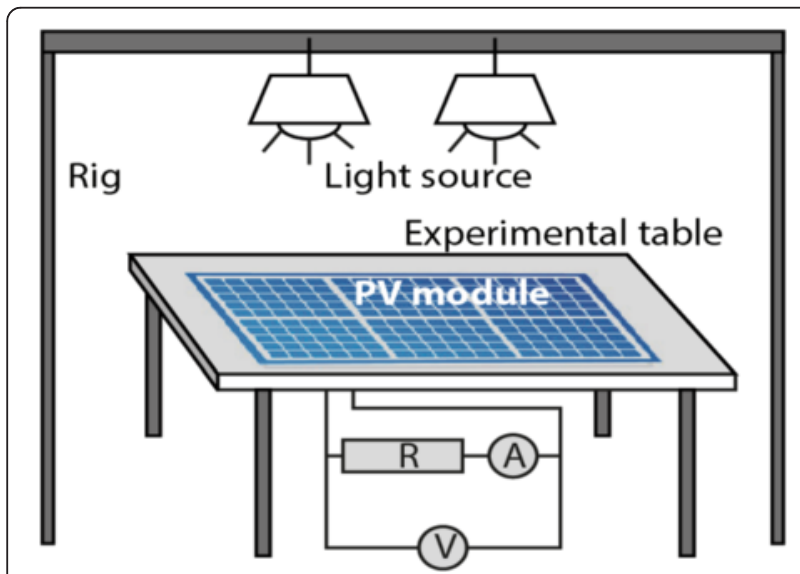

Fig. 3 The experimental set up consists of a table and flat PVmodule, located $0.8 \mathrm{~m}$ beneath two $400 \mathrm{~W}$ artificial light sources (8545 Lumen each). The resistor (R) was constrained, while current $(A)$ and voltage $(V)$ were recorded
Table 1 Module Specifications

\begin{tabular}{lll}
\hline & Module 1 & Module 2 \\
\hline Model & SM 30/36 & ET-M53610 \\
Technology & Monocrystalline & Monocrystalline \\
Dimensions & $675 \times 345 \times 20 \mathrm{~mm}$ & $383 \times 299 \times 35 \mathrm{~mm}$ \\
Number of cells & 36 & 36 \\
Weight & $2.7 \mathrm{~kg}$ & $1.7 \mathrm{~kg}$ \\
Power & $30 \mathrm{~W}$ & $10 \mathrm{~W}$ \\
Nominal voltage & $17.3 \mathrm{~V}$ & $17.82 \mathrm{~V}$ \\
Nominal current & $1.74 \mathrm{~A}$ & $0.57 \mathrm{~A}$ \\
Open-loop voltage & $20.8 \mathrm{~V}$ & $21.96 \mathrm{~V}$ \\
Shortcircuit current & $1.93 \mathrm{~A}$ & $0.63 \mathrm{~A}$
\end{tabular}

Technical specifications for the two PV-modules used in the laboratory experiments. These are referred to as module 1 and module 2 for simplicity

The resistor used in the experiment was an aluminium-housed resistor from Arcol, with specified technical features (resistance $6.8 \Omega$, connection type axial, power $100 \mathrm{~W}$, coil winding technology, temperature coefficient $\pm 100 \mathrm{ppm} /{ }^{\circ} \mathrm{C}$, temperature coefficient max. $-100 \mathrm{ppm} /{ }^{\circ} \mathrm{C}$, tolerance $\pm 5 \%$ ). In addition to the technical data, the I-V-characteristics and the working point (Quaschning and Hanitsch, 1996) of the modules at the standard testing conditions of $1000 \mathrm{~W} / \mathrm{m}^{2}$ insulation and $25{ }^{\circ} \mathrm{C}$ temperature are provided in Additional file 1.

To protect the PV-module from pollution, fouling and other irreproducible results, a transparent thin PVC plate was placed on top of the module. This setup facilitated deposition of tephra and cleaning of the modules, and was similarly applied earlier (Sulaiman et al., 2011). The dried tephra samples were then dispersed onto the modules by letting the tephra rain down from above. This was done by hand and by shaking the PVC plate to keep the distribution of the tephra as homogenous as possible (Fig. 4). We also repeated the experiments multiple times, successfully testing and ensuring the reproducibility of the results. The effect of heterogeneous dispersion, or clustering (Beattie et al., 2012) was not investigated further. Output voltage and current were measured and graphed as they were also used in previous studies (Sulaiman et al., 2011) and allow the calculation of the power generated by the PV-module. This was done using the electrical power equation $\mathrm{P}=\mathrm{V} \cdot \mathrm{I}$ (Quaschning, 2010). After the measurement, the tephra was swept in a box from a known area and weighed. We repeated this process several times with increasing tephra mass until we could determine and verify a clear dependency between the tephra mass and the loss in power of the PV-modules.

Earlier studies showed that the power generation of PV-modules is influenced by their temperature (Skoplaki and Palyvos, 2009). Therefore, artifacts arising from 

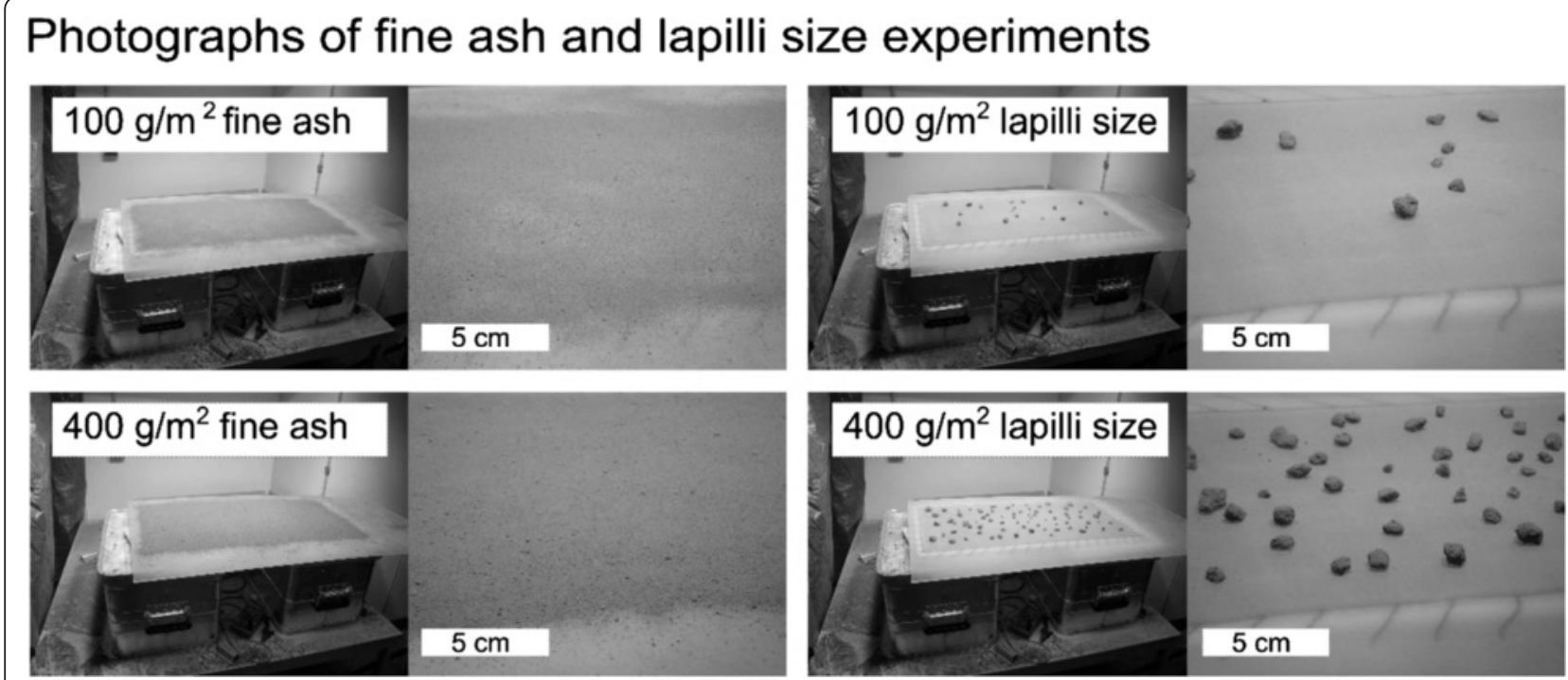

Fig. 4 The photographs show two views on the experimental table with fine ash (left and with lapilli size (right side), where the upper module shows an amount of $100 \mathrm{~g} / \mathrm{m}^{2}$, and the lower module shows $400 \mathrm{~g} / \mathrm{m}^{2}$. Close up views on the table illustrate that the grain size may influence the power generation of the PV-module depending on whether it is entirely covered or still operating. Contrary to the fine and coarse ash coverage, conditions as shown for the lapilli size range are unlikely to be applicable to a real scenario, however the systematic measurements highlight the general grain size dependency of tephra load vs. power output

unstable experimental temperature conditions were minimized by performing the experiments in an insulated bunker building. Temperature effects due to the artificial light sources were determined in benchmark experiments, as detailed in the following section.

\section{Results}

The results of the experiments are presented in three sets. Firstly, benchmark experiments provide an understanding of the general behavior of the modules. Secondly, systematic laboratory experiments are described where the grain size effects are studied generically. Lastly, the Eyjafjallajökull eruption is applied to the previous results and very fine ash dispersion and deposition effects on PV-modules are presented in the context of the case study.

\section{Benchmark experiments}

To investigate the heating effect of the artificial lights on the modules, both voltage and current were measured after switching the lights on. Results confirmed that the current is largely unaffected by heating artifacts, whereas the voltage shows a temperature effect in the first $\sim 30 \mathrm{~min}$ of the experimental run. We displayed our measurements in Additional file 2. Based on these results, we determined that for the chosen experimental set up, before starting the actual measurements, these modules had to heat up for at least $45 \mathrm{~min}$ in order to produce a constant voltage and hence reproducible result. This warm- up time is a known effect (Skoplaki and Palyvos, 2009) and was considered in all later experiments.

The second benchmark experiment was used to determine the decrease of power-output depending on the covered area of the module. For this purpose, the module was simply covered in part by cardboard, in order to confirm the expected linear dependency between covered area and voltage, which to some degree is expected similarly for falling particles (Jiang et al., 2011). Based on this we assume the mass per area of deposited ash would be equivalent to the covered area, whereas for the current, the relation was found to be non-linear (Jiang et al., 2011). These tests will be used for a comparison in the tephra experiments described below and are presented in Additional file 3.

\section{Systematic experiments on tephra deposit parameters}

Before the measurements, the module was cleaned and thermally equilibrated. Immediately after adding tephra, the measurements depict a rapid decrease of power. From multiple experiments with differing tephra mass, we then find a linear and exponential trend for the voltage $(V)$ and current $(I)$, respectively, as shown in Fig. 5. This effect was tested for two modules and both show similar trends, serving as a validation for the general concept regardless of the module specifications. The voltage decreases linearly until a coverage of about $400 \mathrm{~g} / \mathrm{m}^{2}$ of fine ash and $1500 \mathrm{~g} / \mathrm{m}^{2}$ of coarse ash was reached. The current on the other hand displays a steep 


\section{Influence of the deposited amount of tephra}

a Experiment with fine ash:
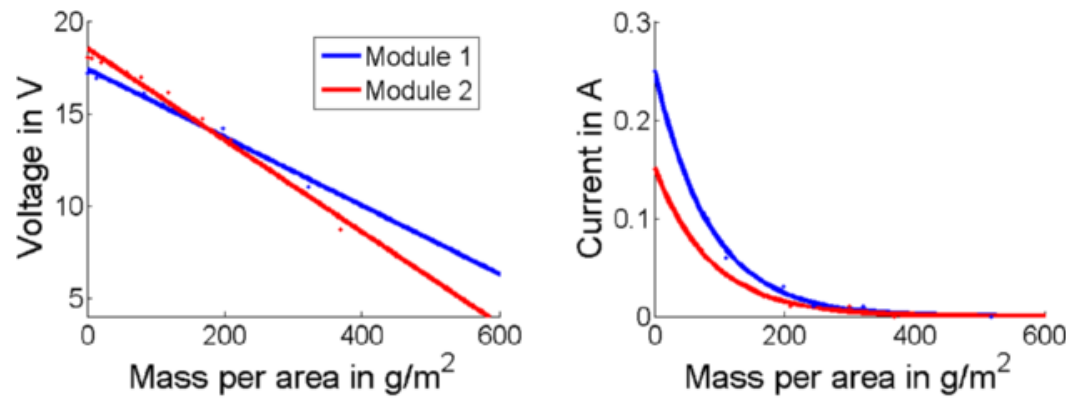

b Experiment with coarse ash:
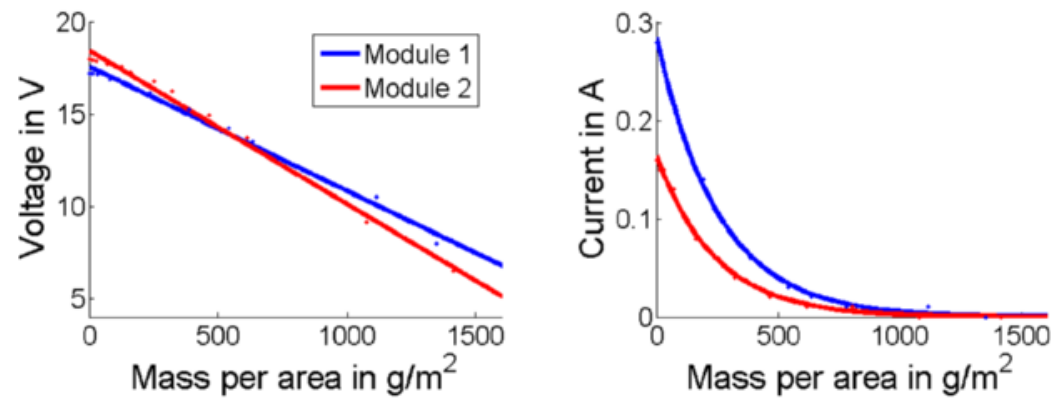

c Experiment with lapilli:
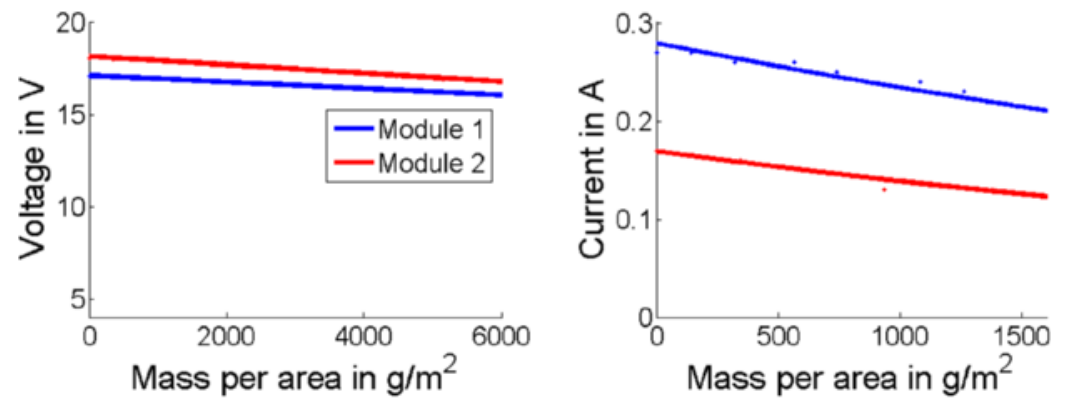

d Grain-size dependence:
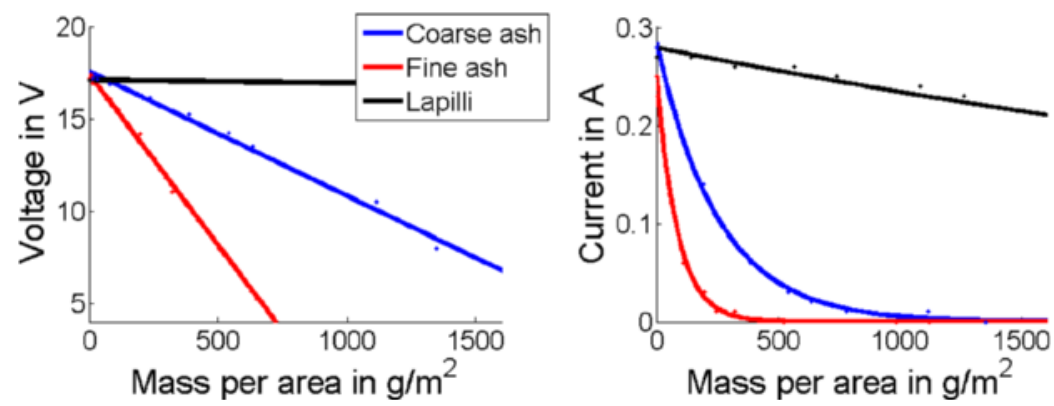

Fig. 5 Results show the influence of deposited amount of tephra $(\mathbf{a}, \mathbf{b}, \mathbf{c})$ and influence of the grain size (d) on the PV-module output voltage (in V) and current (in A). See text for details 
logarithmically decreasing trend. Therefore the amount of ash deposited plays an important role for the power loss of a PV-module, regardless which module was used.

The experiments concerning the influence of different tephra grain sizes deposited on the modules all show a clear decreasing trend with increasing deposited mass (Fig. 5). For a given mass, voltage graphs show a steep decrease for accumulating fine ash, a moderate decrease for coarse ash and a gentle decrease for lapilli size tephra. In general we find that the power PV-modules produce decreases much faster with fine ash than with coarse ash.

The same pattern applies for the current graphs. They show a steeper decrease for fine ash, a moderate decrease for coarse ash and a very gentle near linear decrease for lapilli size tephra. Therefore, the finer the ash is, the less material is needed to significantly reduce the power of a PV-module (Fig. 5d).

\section{Application on Iceland-type eruptions}

To assess the impact of an Iceland-type-eruption on PVmodules, the data from the experiments are compared to the data available from the distribution of the ash cloud during the 2010 Eyjafjallajökull eruption. For a comparison of the experimental results to the Eyjafjallajökull eruption, empirical observations and tephra models for the eruption are considered for the near field (Gudmundsson et al., 2012) and far field (Devenish et al., 2012, Folch et al., 2012, Ripepe et al., 2013), summarized in Fig. 6.

From our experiments we find that a complete failure of the PV-modules would have occurred if tephra fall would have accumulated coarse ash $>1.6 \mathrm{~kg} / \mathrm{m}^{2}$, or if fine ash would have exceeded $0.8 \mathrm{~kg} / \mathrm{m}^{2}$ (Fig. 5). During the 2010 eruption these values were indeed approached by a thin layer of ash only $<1 \mathrm{~mm}$ thick, assuming a mean tephra density of $1400 \mathrm{~kg} / \mathrm{m}^{3}$ as determined in an

\section{Application to the Eyjafjallajokull eruption}

\section{a Near field:}
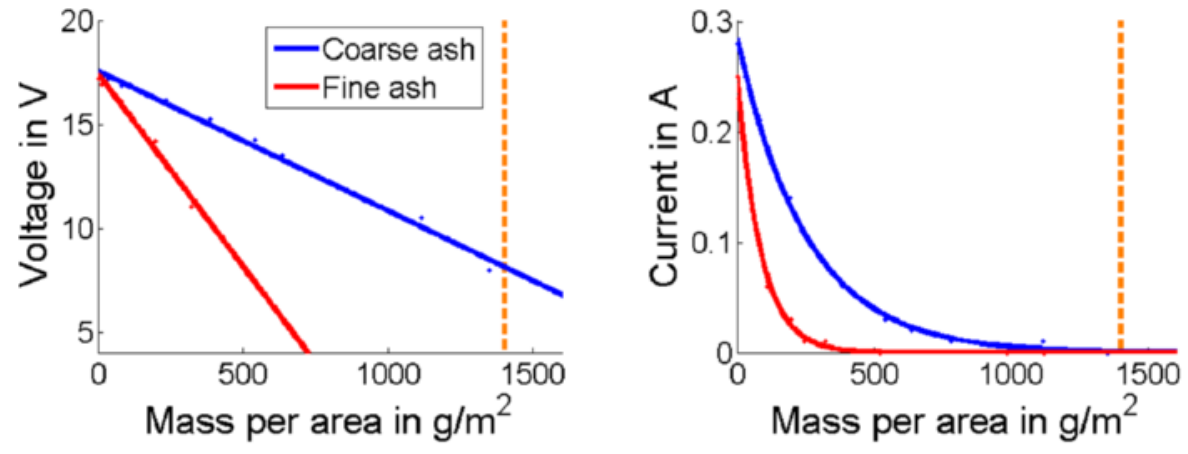

\section{b Far field:}
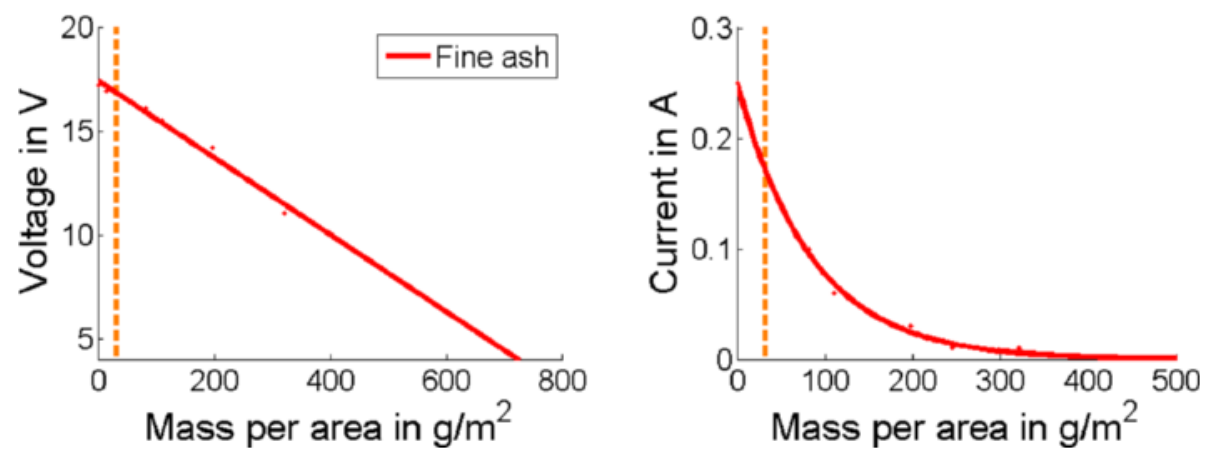

Fig. 6 Results show the near field (a) and the far field (b) application to the Eyjafjallajökull eruption. a Near field: The markers show the ash load of $1400 \mathrm{~g} / \mathrm{m}^{2}$ mass per area (or $0.01 \mathrm{~cm}$ thickness) in $311 \mathrm{~km}$ distance. The electrical power equation reveals that the power would not be completely reduced (at 7-9 V), however as the current is reduced to zero, no electrical power could be produced. $\mathbf{b}$ Far field: The marker shows the load of $32 \mathrm{~g} / \mathrm{m}^{2}$ mass per area over continental Europe between the 14th and 17th of April. For the linear voltage decrease, the effect is found to be not significant. The total loss is only $3.5 \%$ for module 1 and $4.3 \%$ for module 2 . As the current decreases exponentially the loss is much more dramatic than for the voltage. The total power loss is about $32 \%$ for module 1 and $27 \%$ for module 2 
independent study (Gudmundsson et al., 2012), which means ash deposition exceeding $1 \mathrm{~mm}$ would already cause a complete failure. A comparison to the tephra dispersion isopach maps shows that close to the volcano these values were exceeded by far. This $1 \mathrm{~mm}$ isopach extends as far as $\sim 300 \mathrm{~km}$ downwind from the vent, therefore PV-modules located at this distance or closer would have experienced a complete failure. Even at much larger distance a significant loss in power is expected.

In the far field (UK and continental Europe), the effects of the fine Eyjafjallajökull ash deposited on PVmodules can be inferred by considering previous work on the far field distribution of the ash cloud over Europe. The atmospheric ash concentration between the 14th and 17th of April is assumed to be up to $20-32 \mathrm{~g} / \mathrm{m}^{2}$ (Devenish et al., 2012, Folch et al., 2012). Only fine ash can travel far enough for a far field application and therefore only fine ash is considered for this particular scenario. Assuming the deposition of a maximum value $\left(32 \mathrm{~g} / \mathrm{m}^{2}\right)$, fine ash reduces the voltage $(V)$ by $<8 \%$ and the current (I) by $20-30 \%$ (Table 2). Applying the electrical power equation, we estimate the decrease of the PV-module output power is about $30-35 \%$ (Table 2).

Our estimates of reduced power for PV-modules with ash concentrations are comparable to airborne dust settling scenarios tested and based on empirical data, where significant losses are described (Appels et al., 2012, Beattie et al., 2012, Jiang et al., 2011). These far reaching effects are commonly not considered by the renewable energy production industry and may increase their hazard exposure. Our experimental results suggest that the loss of power from every PV-module in the affected area from the 14th to 17th of April 2010 caused by the volcanic ash cloud over Europe may have been significant, however empirical data has yet to be investigated.

Table 2 Estimated power decrease for Europe

\begin{tabular}{lll}
\hline & Module 1 & Module 2 \\
\hline$V_{\text {clear }}$ & $17.41 \mathrm{~V}$ & $18.52 \mathrm{~V}$ \\
$\mathrm{~V}_{\text {ash }}$ & $16.81 \mathrm{~V}$ & $17.73 \mathrm{~V}$ \\
$\Delta \mathrm{V}$ & $0.60 \mathrm{~V} \approx 3.5 \%$ & $0.79 \mathrm{~V} \approx 4.3 \%$ \\
$\mathrm{I}_{\text {clear }}$ & $0.25 \mathrm{~A}$ & $0.15 \mathrm{~A}$ \\
$\mathrm{I}_{\text {ash }}$ & $0.17 \mathrm{~A}$ & $0.11 \mathrm{~A}$ \\
$\Delta \mathrm{I}$ & $0.08 \mathrm{~A} \approx 32 \%$ & $0.04 \mathrm{~A} \approx 27 \%$ \\
$P_{\text {clear }}$ & $4.35 \mathrm{~W}$ & $2.78 \mathrm{~W}$ \\
$P_{\text {ash }}$ & $2.86 \mathrm{~W}$ & $1.95 \mathrm{~W}$ \\
$\Delta \mathrm{P}$ & $1.49 \mathrm{~W} \approx 34.3 \%$ & $0.83 \mathrm{~W} \approx 29.9 \%$
\end{tabular}

Expected reduction in voltage $(\mathrm{V})$, current $(\mathrm{I})$ and power $(\mathrm{P})$ for PV-modules 1 and 2 using the ash concentration $\left(0.32 \mathrm{~g} / \mathrm{m}^{2}\right)$ over Europe during the 2010 Eyjafjallajökull eruption. This shows the estimated impacts to PV-modules located in Europe based on our laboratory experiments

\section{Discussion}

The photovoltaic industry is one of the fastest growing industries in the renewable energy sector, increasing by approximately $40 \%$ annually and reaching tens of gigawatts' production globally (Razykov et al., 2011). PV-modules are increasingly used as a power source for remote stations and buildings, water pumping, home systems, global communications, unmanned and remotely operating robotics and space vehicles as well as for megawatt-scale power plants (Parida et al., 2011). The effect of dust on photovoltaic modules is well studied both empirically and experimentally and could show that amount of dust and type of dust strongly affect the power generation of the modules (Kumar et al., 2013). Dust in the atmosphere is known to settle and affect PV-modules, where small masses of a few tens of grams lead to an PV-power reduction on the order of 10 or even 20 percent (Appels et al., 2012, Beattie et al., 2012, Eldin et al., 2013, Jiang et al., 2011). The effect of volcanic eruptions, especially the different grain size contributions of tephra, however, remained to be studied yet. Our work shows that volcanic eruptions at distances of over $2000 \mathrm{~km}$ may, within a very short time, have an effect that is comparable to atmosphere dust deposition. As we tested, volcanic tephra deposition may have local, regional or continental consequences on PV-modules, and therefore a proper understanding of these hazards is highly relevant, specifically for the renewable energy sector.

Our experimental analysis shows how the poweroutput of a PV-module will rapidly decrease when it is covered by volcanic tephra from an eruption as an increasing mass of deposited tephra prevents incoming light from reaching the module. The particle size of the tephra also plays an important role, rather than just the pure mass. As finer tephra particles are much smaller, they pack more densely. Thus, finer material blocks incoming light more effectively with less material.

Larger, more explosive and voluminous eruptions, especially in association with water (phreatomagmatic eruptions), produce a greater amount of fine ash, which can be transported by wind over long distances. This would mean the ash would not only affect geophysical instruments powered by PV-modules in the near field of the volcano, but also industrial and private instruments in the mid and far field. Nowadays investigation into this matter has become especially important as the dependency to PV-modules is widespread and covering not only scientific devices in the field but also industry sectors of various branches. Before discussing the implications of this work, we critically assess the limitations of the data, approaches and assumptions made in here. 


\section{Expexrimental setup limitations}

We assumed that PV-modules are laid down horizontally, so that tephra dispersion assumptions can be directly related to the experimental results. This was necessary, as we had to protect the PV-modules from pollution with a PVC plate, which combined with our experimental setup only allowed for horizontal measurements. In reality, PV-modules are set up inclined, facing towards the sun. In high latitudes, and in Iceland specifically, PV-modules are often set up near vertical, prohibiting coverage not only by dust and snow, but also by tephra. Hampton et al. (2015) recently found that tephra accumulation is severely reduced with an angle steeper than $35^{\circ}$ as the tephra starts to shed off. Generally flat PV-modules tend to be blind earlier, which is why we expect the effects of PV-coverage to be more relevant in areas of low latitude zones as described for dust deposition (Beattie et al., 2012).

The experimental set-up and the overall accuracy of all experiments is easily reproducible, nevertheless a few possible error sources have to be mentioned. The heating effect was taken into account for all measurements, meaning that the tephra deposition started after reaching a stable voltage. With a greater mass of tephra on the module however, a cooling effect started to oppose the heated modules as the tephra was rather cool and the voltage went up as long as the tephra stayed on the module. As the results were taken immediately after the deposition, the error is probably small.

Another issue to mention originates from our artificial light sources. Due to the experiments having to be conducted inside, we used simple lights sources with properties as described in section Experimental setup. These lights were not designed to generate wavelengths representing sunlight, which is likely to affect our results as we experienced a very low amount of generated power. However the general trends of our measurements should still be representative, which is supported by the fact that the trend of power reduction was almost identical for both modules (Fig. 7). Furthermore, any effects involving the absorption of certain wavelengths due to the tephra deposition were not considered, as we assume the tephra to block the incoming light entirely.

To minimize errors in the trends and for comparability, all experiments were conducted with the same transparent PVC plate. This means that the overall results are constant for all measurements, although being slightly biased by the PVC plate as the light has to pass through another transparent medium, which may result in small measurement artifacts. It also elevates the tephra slightly above the PV-module and may allow light to pass through the sides. Although these effects could not be quantified in detail, they cannot be excluded. The tephra experiments generally show a decrease in current with

\section{Power reduction of the PV-modules due to fine ash}

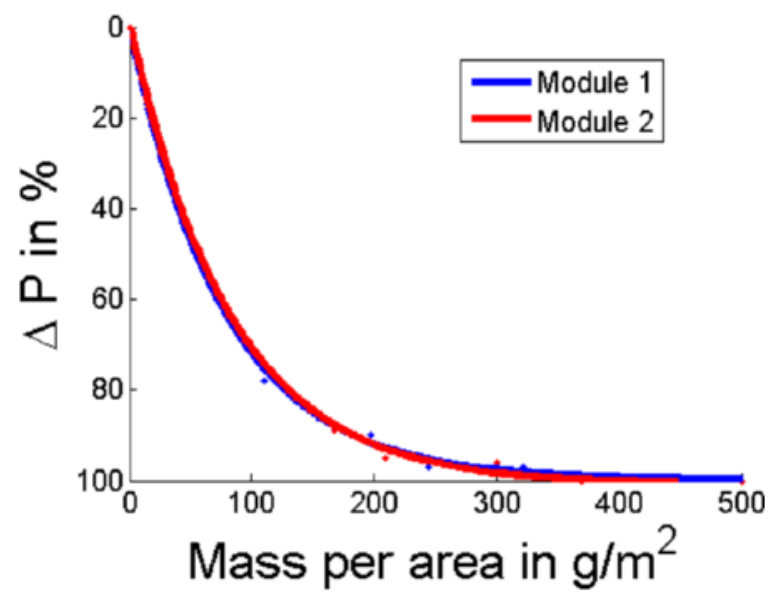

Fig. 7 The power reduction of the modules caused by the fine ash: The trends (module 1 and module 2) are nearly identical, so it is likely that other PV-modules will show the same trend

increasing coverage, but even with nearly $6 \mathrm{~kg} / \mathrm{m}^{2}$ coverage, when the module is completely covered with a thick layer of tephra, the voltage never decreased below about $3 \mathrm{~V}$ (Additional file 4). We interpret this as an artifact from the transparent PVC plate located between the tephra and the module, where by refraction and reflection some light can still pass through the sides. As we were unable to fix this issue in our experiments, we excluded data points from our measurements in high tephra mass ranges which showed this effect. These points were easily recognizable as the deteriorated strongly from the general trend of voltage decrease below the $3 \mathrm{~V}$ stated above, however it is likely that the other points are also biased through this effect, although probably only slightly.

The experiments described assume dry conditions. However PV-power generation may dramatically change if humidity changes and rain falls (Mekhilef et al., 2012). We briefly tested the effects of liquid water marginally. For this purpose we sprayed drizzle size water droplets $(<0.5 \mathrm{~mm})$ on the module with a vaporizer controlling the amount of water used. The results are displayed in Table 3 and show that water slightly enhances the power

Table 3 Water influence

\begin{tabular}{llll}
\hline & $\begin{array}{l}\text { Dry, before } \\
\text { spraying }\end{array}$ & Wet & Dried out \\
\hline Fine ash $\left(204 \mathrm{~g} / \mathrm{m}^{2}\right)$ & $15.92 \mathrm{~V} / 0.01 \mathrm{~A}$ & $17.16 \mathrm{~V} / 0.02 \mathrm{~A}$ & $16.19 \mathrm{~V} / 0.01 \mathrm{~A}$ \\
Coarse ash $\left(207 \mathrm{~g} / \mathrm{m}^{2}\right)$ & $19.38 \mathrm{~V} / 0.06 \mathrm{~A}$ & A $19.40 \mathrm{~V} / 0.07 \mathrm{~A}$ & $19.24 \mathrm{~V} / 0.06 \mathrm{~A}$ \\
Without ash & $20.4 \mathrm{~V} / 0.15 \mathrm{~A}$ & $20.4 \mathrm{~V} / 0.16 \mathrm{~A}$ & $20.4 \mathrm{~V} / 0.15 \mathrm{~A}$
\end{tabular}

Difference in the voltage and current of PV-module 2 under dry and wet conditions with and without tephra present, simulating the effects of rain 
PV-modules produce, as long as they are still wet. Voltage as well as current seem to increase when water is sprayed over the modules. When drying out however, the effect is lost or even reversed. Adding more water may lead to a cleansing effect of the PV-modules, increasing again their power generation. Because this effect depends on the amount of water, droplet size and drying conditions, this effect warrants a more detailed study that cannot be extensively described in this paper.

\section{Further assumptions}

Our experimental simulations for the three main grain size fractions produced during the Eyjajfallajökull eruption involved several simplifications. The assessment for the loss of power through deposition of ash is done under the assumption that the ash was completely deposited on the modules. For the near field application this assumption is very realistic, as the isolines of the thickness of the ash layer were used to compare the deposited material around the volcano with the deposited material in the experiments. This facilitates the precision of the estimation of the mass per area to distance correlation. However, it should be mentioned that the isolines downwind, which were used for the maximum blackout distance, went over the sea to the southeast of the crater. This means the thickness of the ash layer was not directly accessible and is thus not very precise.

For the far field application the situation is different. As there was no visible deposition of ash on the European continent, the simulated ash concentration in the air was used instead. In contrast to the near field application, the assumption of the complete deposition of the ash is rather unrealistic. Only fine ash has the suspension characteristics to be transported further than a few kilometers away from the crater and is therefore the only ash particle size that will have been in the air over Europe (Parfitt and Wilson, 2008). However, this means that the ash will probably tend to stay suspended in the air for several days. Commonly the ash will be washed out of the air by periodical rainfall and deposited slowly over time. In that case, the proposed $30 \%$ power reduction would not be directly measurable. Instead there would be reductions on a much smaller scale caused by the occasional deposition of ash through rain, but over a long period after the eruption with the length of the period depending on the amount of ash suspended in the air.

For practical reasons, we assume the fine grained deposits are appropriate to simulate far field effects. This is a simplification, as the fine grained ash particles used for this study were sampled in the near field. Ash samples in the far field have had a particle dimension even smaller than the one used by our fine grained ash simulations (Weber et al., 2012). Given that our experiments show that the fine ash causes a much more severe reduction in output power at PV-modules than coarser ash, it is likely that such measurements would have experienced a slightly stronger reduction with the same amount of ash. Overall however, our discussed effects in the far field (PV-power reduction by $30 \%$ ) probably overestimates the reality due to our assumption of complete ash deposition as well as the horizontal setup of our PV-modules. Furthermore, the $0.32 \mathrm{~g} / \mathrm{m}^{2}$ airborne ash concentration used for the calculation is a maximum value, meaning that for the parameters of the 2010 Eyjafjallajökull eruption, 30 \% PV-power reduction for Europe is a worst case scenario.

\section{Maintenance issues}

PV-modules are requiring relatively little maintenance work, which is one of the main reasons they are so widely used and implemented (Yachi and Yamanaka, 2000). PV-modules exposed to dust and other environmental agents, however, may quickly lose their output power. As we show in this work, volcanic tephra generated by moderate sized eruptions may lead to a significant reduction of the $\mathrm{PV}$-module power, with reductions on the order of 20-30 percent over thousands of kilometers distance to the erupting volcano. Therefore volcanic activity has to be considered in PV-module maintenance plans, even if there is no active volcano in the immediate surroundings. Considering the experimental relationship of power loss to tephra coverage we highlight two important implications. Firstly, the detection of a significant power loss may be used as an initiator for updating maintenance plans with cleaning intervals that restore the modules for further use. Secondly, the detection of a power loss can be used to infer and monitor the amount of tephra deposition. For this purpose, "reference panels" can be installed as already suggested in detail for other non-volcanic pollutants (Catelani et al., 2012), which might warrant further studies in the future.

Maintenance plans in the near field are likely to be affected much more severely compared to the far field. Near field PV-modules are commonly also used for volcano monitoring purposes, where geophysical and geochemical recordings are gathered and data is transmitted to volcano observatories. The continuity of the instrument operation is vital, as hazard assessments and civil protection measures highly depend on such near field data. This problem seems obvious, but every year large and tephra producing volcanic eruptions lead to instrumental failure due to tephra coverage. Therefore volcanic crises are often difficult to monitor from near field stations, leaving room for speculations and even false alarms. Because updated maintenance plans are hazardous to realize during a volcanic eruption, the PV-modules 
should be installed either steeply inclined or protected, or other power sources should be used in addition.

\section{Relevance for other eruptions}

An Eyjafjallajökull-type eruption may produce an ash cloud that might cause a total blackout on PV-modules within a distance of about 300 kilometer downwind from the crater and that had the potential to reduce the power of PV-modules in the far field over continental Europe by up to $30 \%$. These results show, that the deposition of volcanic tephra can heavily reduce the power produced by photovoltaic modules. It has been shown, that particularly the fine grained tephra fragments cause the heaviest reduction with the least amount of tephra. Fine ash is also the grain size range most likely to be transported long distances as it can stay suspended in the air for days.

However, with a VEI of 3-4, the 2010 Eyjafjallajökull eruption was rather modest (Gudmundsson et al., 2012). The special characteristics were the combination of the long eruption period and the constant wind in south eastern direction, which caused so much ash to reach the mainland in Europe. Under similar circumstances, eruptions exceeding VEI 3-4 could have a much more damaging effect. Eruptions with a VEI of 3 happen about 3 times a year on Iceland alone, and there are about 2025 eruptions per century. Over Europe since 1995, nine significant volcanic eruptions occurred in total with VEI of 3 or larger (2 times at Hekla, 3 times at Grimsvötn, 1 time at Eyjafjallajökull, 3 times at Etna) with aircraft ash encounters (Hekla 1991 and 2000) and partial closure of air space (Hekla 1991, 2000, Etna 2002, Eyjafjallajökull 2010). Considering the catalogue of the global volcanism program (Simkin et al., 2001), every 4-6 years an eruption occurs on Europe with a VEI of 3 or larger. Therefore similar or stronger eruptions within the coming decades are highly probable. Katla in particular, which is located next to Eyjafjallajökull, poses a significant threat in terms of magma production. Katla has been the most productive volcano in Iceland and is known for major eruptions reaching a VEI of 5 (Thordarson and Larsen, 2007). Calculations of the future eruption risk show that the probability for another eruption is $17 \%$ in the next 10 years and $60 \%$ within the next 60 years (Elíasson, 2014) with high potential to affect continental Europe (Weber et al., 2012). Other Icelandic volcanoes that have been known to produce tephra and might pose similar threats are Hekla, Askja, or Grimsvötn. Recently, the eruption of the Bárðarbunga volcanic system luckily did not occur under a major ice cap, resulting in little tephra production. Purely in terms of magma volume, this eruption was ten times larger than Eyjafjallajökull in 2010 (Sigmundsson et al., 2014).
Apart from Icelandic volcanoes, our results likely have important implications for other regions. While the general trend with which the PV-power decreases should be applicable to any tephra producing eruption scenario, our results are probably most applicable for volcanoes in equatorial regions where PV-modules are placed horizontally. Especially for countries around the Pacific ring of fire, which display a very high frequency of volcanic eruptions and tephra production (Siebert et al., 2011), our results may have significant implications concerning PV-power generation and highlight the potential effects of frequently active volcanoes in these regions. Thus, it would be advisable both for local and overseas authorities to consider scenarios of far-reaching tephra dispersion, to be able to effectively mitigate the impacts of volcanic tephra deposition on PV-modules.

\section{Conclusion}

We conducted experiments to explore the influence of volcanic tephra deposition on the power generation of PV-modules. Our experiments shows that even minor loads of volcanic tephra deposited on a PV-module can severely decrease their performance. We showed that with an increasing tephra load, voltage decreases linearly whereas current displays an exponentially decreasing trend. We also found a strong grain size dependency, with finer particles causing a much more drastic decrease as coarser particles with the same tephra load.

We applied our results to the 2010 Eyjafjallajökull eruption and found that the eruption had the capability to cause a complete failure of all PV-modules within $300 \mathrm{~km}$ downwind from the volcano and to reduce the electrical power generated by PV-modules in Europe by up to $30 \%$ (although this value is likely an overestimate). The prolonged and constant generation of volcanic tephra, especially in fine grain size ranges, the suspension characteristics of the ash as well the southeastern wind conditions at the time were the main controlling factors governing the spread of the ash cloud and resulting in such widespread effects.

With respect to the frequency of similar eruptions it is very likely that volcanic tephra will cause problems for electric power generated by PV-modules in the future. Also, considering the rapidly growing photovoltaic industry and the importance of PV-modules for scientific purposes and volcano monitoring, these issues may be of increasing significance. Our study is the first to detail a simple approach to assess the effects of volcanic tephra on PV-modules that, although very basic, is applicable to all explosive volcanic eruptions around the globe. More accurate assessments, especially regarding the impacts on volcanic tephra on PV-modules, are required and we highly encourage further and more detailed research into these issues. 


\section{Additional files}

Additional file 1: I-V-Characteristics for the PV-modules derived from the manufacturer's information and the resistor. The extreme points are the peak-power point, the short circuit current and the openloop voltage. (PDF $190 \mathrm{~kb}$ )

Additional file 2: Heating effect in relation to time: The voltage decreases exponentially and reaches a stable value after approximately 45 minutes. (PDF $95 \mathrm{~kb}$ )

Additional file 3: Voltage and current decrease in relation to area coverage by cardboard: The voltage decreases with a linear trend, whereas the current drops exponentially. (PDF $98 \mathrm{~kb}$ )

Additional file 4: With $6 \mathrm{~kg} / \mathrm{m}$ the module is completely covered in ash, yet the voltage did not decrease below about $3 \mathrm{~V}$. This is likely due to the use of the PVC plate. (PDF $79 \mathrm{~kb}$ )

\section{Acknowledgements}

This paper benefited greatly from very constructive reviewers. Prof. Magnús Tumi Guðmundsson and Prof. Ármann Höskuldsson for friendly communication and the shipping of the fresh set of tephra-samples. Prof. Rutger Schlatmann for the short term acceptance for revision and grading of the thesis this study is based on as well as his instructions on the functional principles of PV-modules and the providing of materials for research. Nicole Richter, Michele Pantaleo, Mehdi Nikkhoo for assistance and feedback regarding content and presentation of the material. Tanja Witt for helpful and friendly tips, experiences and suggestions concerning the writing of this study and finally Joanna Gaset and Marcus Trimble for proofreading the manuscript. Financial support was provided by the FUTUREVOLC project (No 308377) and the GFZ Potsdam.

Received: 20 March 2015 Accepted: 18 December 2015

Published online: 11 January 2016

\section{References}

Appels R, Muthirayan B, Beerten A, Paesen R, Driesen J, Poortmans J. The effect of dust deposition on photovoltaic modules. 38th IEEE Photovoltaic Specialists Conference. 2012. p. 1886-9.

Backus C, Barnett A, Feucht D. Special Issue on Photovoltaic Materials, Devices and Technologies - Foreword. leee T Electron Dev. 1990;37(2):329-9.

Beattie NS, Moir RS, Chacko C, Buffoni G, Roberts SH, Pearsall NM. Understanding the effects of sand and dust accumulation on photovoltaic modules. Renew Energy. 2012;48:448-52

Cabanillas RE, Munguía H. Dust accumulation effect on efficiency of Si photovoltaic modules. J Renewable Sustainable Energy. 2011;3(4):1-8

Catelani M, Ciani L, Cristaldi L, Faifer M, Lazzaroni M, Rossi M. Characterization of photovoltaic panels: The effects of dust. 2012 IEEE International Energy Conference and Exhibition, ENERGYCON 2012. 2012. p. 45-50.

Devenish BJ, Thomson DJ, Marenco F, Leadbetter SJ, Ricketts H, Dacre HF. A study of the arrival over the United Kingdom in April 2010 of the Eyjafjallajökull ash cloud using ground-based lidar and numerical simulations. Atmos Environ. 2012;48:152-64.

Eldin AMAMS, Abel-Rahman AK, Ali AHH, Ookawara S. Effect of dust deposition on performance of thin film photovoltaic module in harsh humid climate In: Proceedings of 2013 International Conference on Renewable Energy Research and Applications, ICRERA 2013. 2013. p. 674-9.

Elíasson J. Katla volcano in Iceland, potential hazards and risk assessment. Nat Sci. 2014:6(3):1-9

Elminir HK, Ghitas AE, Hamid RH, El-Hussainy F, Beheary MM, Abdel-Moneim KM. Effect of dust on the transparent cover of solar collectors. Energy Convers Manag. 2006:47(18-19):3192-203.

Folch A, Costa A, Basart S. Validation of the FALL3D ash dispersion model using observations of the 2010 Eyjafjallajökull volcanic ash clouds. Atmos Environ. 2012:48:165-83.

Goossens D, Offer ZY, Zangvil A. Wind tunnel experiments and field investigations of eolian dust deposition on photovoltaic solar collectors. Sol Energy. 1993;50(1):75-84.

Gudmundsson MT, Thordarson T, Hoskuldsson A, Larsen G, Bjornsson H, Prata FJ, et al. Ash generation and distribution from the April-May 2010 eruption of Eyjafjallajökull, Iceland. Sci Rep. 2012;2:1-12.
Hampton SJ, Cole JW, Wilson G, Wilson TM, Broom S. Volcanic ashfall accumulation and loading on gutters and pitched roofs from laboratory empirical experiments: Implications for risk assessment. J Volcanol Geotherm Res. 2015:304:237-52

Jenkins SF, Spence RJS, Fonseca JFBD, Solidum RU, Wilson TM. Volcanic risk assessment: Quantifying physical vulnerability in the built environment. J Volcanol Geotherm Res. 2014;276:105-20.

Jiang H, Lu L, Sun K. Experimental investigation of the impact of airborne dust deposition on the performance of solar photovoltaic (PV) modules. Atmos Environ. 2011;45(25):4299-304.

Ju F, Fu X. Research on Impact of Dust on Solar Photovoltaic (PV) Performance. 2011 International Conference on Electrical and Control Engineering, ICECE 2011 - Proceedings. 2011. p. 3601-6.

Kaldellis JK, Kapsali M. Simulating the dust effect on the energy performance of photovoltaic generators based on experimental measurements. Energy. 2011;36(8):5154-61.

Kumar ES, Sarkar B, Behera D. Soiling and dust impact on the efficiency and the maximum power point in the photovoltaic modules. Int J Eng Res Technol. 2013;2(2):1-8.

Le Bas M, Streckeisen A. The IUGS systematics of igneous rocks. J Geol Soc. 1991;148(5):825-33.

Mekhilef S, Saidur R, Kamalisarvestani M. Effect of dust, humidity and air velocity on efficiency of photovoltaic cells. Renew Sust Energ Rev. 2012;16(5):2920-5.

Mohamed AO, Hasan A. Effect of dust accumulation on performance of photovoltaic solar modules in Sahara environment. J Basic Appl Sci Res. 2012;2(11):11030-6

Ndiaye A, Kébé CM, Ndiaye PA, Charki A, Kobi A, Sambou V. Impact of dust on the photovoltaic (PV) modules characteristics after an exposition year in Sahelian environment: The case of Senegal. Int J Phys Sci. 2013;8(21):1166-73.

O'Regan M. On the edge of chaos: European aviation and disrupted mobilities. Mobilities. 2011;6(1):21-30.

Ota Y, Araki K, Nishioka K. Impact of volcanic ash on CPV system in Miyazaki Japan. AIP Conference Proceedings. 2012. p. 340-3.

Oxford Economics. The Economic Impacts of Air Travel Restrictions Due to Volcanic Ash, Report. Oxford, UK: Abbey House; 2010. p. 1-15.

Oze C, Cole J, Scott A, Wilson T, Wilson G, Gaw S, et al. Corrosion of metal roof materials related to volcanic ash interactions. Nat Hazards. 2014;71(1):785-802.

Parfitt L, Wilson L. Fundamentals of Physical Volcanology. 250 Main Street, Malden, MA 02148-5020, USA: Blackwell Publishing; 2008.

Parida B, Iniyan S, Goic R. A review of solar photovoltaic technologies. Renew Sust Energ Rev. 2011;15(3):1625-36.

Quaschning V. Renewable Energy and Climate Change. John Wiley \& Sons Ltd, The Atrium, Southern Gate, Chichester, West Sussex, PO19 8SQ, United Kingdom; 2010

Quaschning V, Hanitsch R. Numerical simulation of current-voltage characteristics of photovoltaic systems with shaded solar cells. Sol Energy. 1996;56(6):513-20.

Rajput DS, Sudhakar K. Effect of dust on the performance of solar PV panel. Int J ChemTech Res. 2013;5(2):1083-6.

Razykov TM, Ferekides CS, Morel D, Stefanakos E, Ullal HS, Upadhyaya HM. Solar photovoltaic electricity: Current status and future prospects. Sol Energy. 2011:85(8):1580-608.

Ripepe M, Bonadonna C, Folch A, Delle Donne D, Lacanna G, Marchetti E, et al. Ash-plume dynamics and eruption source parameters by infrasound and thermal imagery: The 2010 Eyjafjallajökull eruption. Earth Planet Sci Lett. 2013:366:112-21.

Saga T. Advances in crystalline silicon solar cell technology for industrial mass production. NPG Asia Materials. 2010;2(3):96-102.

Schlosser V, Drapalik M, Klinger G. About the usability of a photovoltaic module to monitor air pollution. 3rd International Conference on Clean Electrical Power: Renewable Energy Resources Impact. ICCEP. 2011;2011:434-8

Siebert L, Simkin T, Kimberly P. Volcanoes of the World, Third edition. Berkeley and Los Angeles, California, USA: University of California Press; 2011

Sigmundsson F, Hooper A, Hreinsdóttir S, Vogfjörd KS, Ófeigsson BG, Heimisson $E R$, et al. Segmented lateral dyke growth in a rifting event at Bárðarbunga volcanic system, Iceland. Nature. 2014;517(7533):191-5.

Simkin T, Siebert L, Blong R. Volcano fatatities - Lessons from the historical record. Science, 2001:291(5502):255-5.

Skoplaki E, Palyvos JA. On the temperature dependence of photovoltaic module electrical performance: A review of efficiency/power correlations. Sol Energy. 2009;83(5):614-24. 
Sorloaica-Hickman N, McFall J, Nason S, Davis K, Arens E. Optimization of the photovoltaic powered systems with dust mitigation technology for future lunar and martian missions. Conference Record of the IEEE Photovoltaic Specialists Conference. 2012. p. 2815-8.

Sulaiman SA, Hussain HH, Leh N, Razali MS. Effects of dust on the performance of PV panels. World Acad Sci Eng Technol. 2011;58:588-93.

Sulaiman SA, Singh AK, Mokhtar MMM, Bou-Rabee MA. Influence of dirt accumulation on performance of PV panels. Energy Procedia. 2014;50:50-6.

Thordarson T, Larsen G. Volcanism in Iceland in historical time: Volcano types, eruption styles and eruptive history. J Geodyn. 2007;43(1):118-52.

Tilling RI. Volcano hazards. In: Ernst G, editor. Marti, J. Cambridge: Volcanoes and the Environment. Cambridge University Press; 2005.

Wardman J, Wilson T, Hardie S, Bodger P. Influence of volcanic ash contamination on the flashover voltage of HVAC outdoor suspension insulators. IEEE Trans Dielectr Electr Insul. 2014:21(3):1189-97.

Wardman JB, Wilson TM, Bodger PS, Cole JW, Johnston DM. Investigating the electrical conductivity of volcanic ash and its effect on HV power systems. Phys Chem Earth. 2012;45-46:128-45.

Weber K, Eliasson J, Vogel A, Fischer C, Pohl T, van Haren G, et al. Airborne in-situ investigations of the Eyjafjallajökull volcanic ash plume on iceland and over north-western Germany with light aircrafts and optical particle counters. Atmos Environ. 2012:48:9-21.

Wilson G, Wilson TM, Deligne NI, Cole JW. Volcanic hazard impacts to critical infrastructure: A review. J Volcanol Geotherm Res. 2014;286:148-82.

Wilson G, Wilson T, Cole J, Oze C. Vulnerability of laptop computers to volcanic ash and gas. Nat Hazards. 2012;63(2):711-36.

Yachi T, Yamanaka T. Research and development in the area of clean energy. NTT Rev. 2000;12(5):19-23.

Zorn E. Influence of volcanic ash on photovoltaic (PV)-modules: Analysis and application to the 2010 Eyjafjallajökull eruption, Iceland. Bachelor Thesis. Potsdam: Universität Potsdam; 2014. p. 1-37.

Zorrilla-Casanova J, Piliougine M, Carretero J, Bernaola-Galván P, Carpena P, Mora-Lõpez $\mathrm{L}$, et al. Losses produced by soiling in the incoming radiation to photovoltaic modules. Prog Photovolt Res Appl. 2013;21(4):790-6.

\section{Submit your manuscript to a SpringerOpen ${ }^{\circ}$ journal and benefit from:}

- Convenient online submission

- Rigorous peer review

- Immediate publication on acceptance

- Open access: articles freely available online

High visibility within the field

- Retaining the copyright to your article 